\title{
On the Treatment of Soils by Carbon Bisulphide.
}

\author{
By \\ T. Takeuchi. \\ College of Agriculture and Forestry, Kagoshima.
}

For the passed ten years many experiments have been described, that demonstrated a beneficial effect upon the yield of crops when the soils were treated with disinfectants. In most of these cases carbon bisulphide had been applied. Recently however HILTNER has observed that carbolineum ${ }^{1)}$ was still superior to carbon bisulphide, but its application should take place at least four months before sowing or planting, or in the previous autumn.

The explanations thus far given for the phenomenon differ, but so much is surely established that by the use of disinfectants many organisms present in the soils are killed-bacteria, infusoria, worms also parasitic organisms-and thus much nitrogenous material becomes available, also phosphate of potassium. ${ }^{2)}$ In consequence the bacterial mass depressed at first, will increase later on in a much higher measure as they had been present before, as soon as the disinfectant material has volatilised or been washed out or destroyed in one way or other. A great part however of the nitrogen and of potassium phosphate liberated will benefit the roots of crops grown on that soil.

When soils are manured for many years or decades or even centuries with rich nitrogenous manures-as in Japan-a large

1. Carbolineum is cheaper than carbon bisulphide and meor convenient for transporting and keeping. 100 kilo cost 10-15 yen. It is a product of fractional coal ar distillation and consists of a mixture of various phenols with hydrocarbons. It is imported into Japan by Weinterger \& Co. in Yokohama. p. 443.

2. Cf. O. Loew and K. Aso, Bulletin, College of Agriculture, Tokyo, Vol. VII., 
part of that nitrogen will pass into an unavailable form, partly in the form of bacteria and animals, partly in insoluble humus compounds. In the latter case, oxidizing media, as chloride of lime or bleaching powder and potassium permanganate might liberate a part of that nitrogen as ammonia, when a part of the carbon is oxidized. For this reason I have applied in my experiment not only bisulphide of carbon, but for comparison also potassium permanganate. The writer also intends to apply next year also chlorlde of lime.

The soil chosen for my experiment was a loamy humus and yielded on analysis the following figures, when analysed in the ustual way:

Moisture . . . . . . . . . . 3.50

Loss on ignition . . . . . . . 10.08

Humus . . . . . . . . . . . 1449

Nitrogen . : . . . . . . . . 0.30

Insoluble in hot $\mathrm{HCl}$. . . . . . 75.05

Silica soluble in hot $\mathrm{HCl}$. . . . 0.43

Silica soluble in $\mathrm{Na}_{2} \mathrm{CO}_{3}$.

Sum of Silica . . . . . . . . . 9.01

$\mathrm{Al}_{2} \mathrm{O}_{3}$. . . . . . . . . . 6.16

$\mathrm{Fe}_{2} \mathrm{O}_{3}$. . . . . . . . . . . 2.01

$\mathrm{FeO}$. . . . . . . . . . . . 0.45

$\mathrm{Mn}_{2} \mathrm{O}_{3}$. . . . . . . . . . . 0.14

$\mathrm{CaO}$. . . . . . . . . . 1.24

$\mathrm{MgO}$. . . . . . . . . . . . 0.91

$\mathrm{K}_{2} \mathrm{O}$. . . . . . . . . . . 0.09

$\mathrm{Na}_{2} \mathrm{O}$. . . . . . . . . . 0.23

$\mathrm{P}_{2} \mathrm{O}_{5}$. . . . . . . . . . . . 0.12

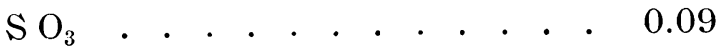

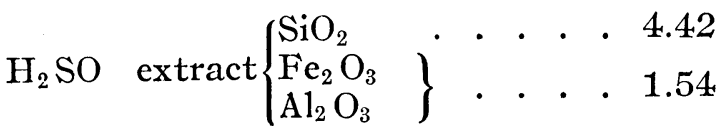

In a second trial the available amounts of lime and Mag- 
nesia were determined after KATAYAMA's method $^{3}$ and found $\mathrm{CaO}=0.64 \%, \mathrm{MgO}=0.21 \%$.

This analysis is quite instructive in several ways. In the first place it shows that there is enough humus to insure a good absorptive power of the soil. In the second place the nitrogen content is shown to be high, inasmuch $0.3 \%$ correspond to a depth of $10 \mathrm{~cm}$. and a surface of a hectar $=2250$ kilos. But to the largest part this nitrogen is not directly available. The content of $\mathrm{P}_{2} \mathrm{O}_{5}$ and $\mathrm{K}_{2} \mathrm{O}$ is only moderate. The content of $\mathrm{FeO}$ (besides $\mathrm{Fe}_{2} \mathrm{O}_{3}$ ) is suspicious and may indicate the presence of reducing bacteria, which under certain conditions can exert a noxious action on the roots. Also the high content of silica soluble in sodium carbonate is of a certain interest. As to the content of lime and magnesia, the figures show a favorable lime factor for various crops.

In my first experiment four plots each of 1 sq. metre surface and surrounded by wooden frames were selected and the following manure applied, per plot:

Compost . . . . . . . . . . $562 \mathrm{~g}$.
Superphosphate of lime . . . . $20 \mathrm{~g}$.
Wood ash . . . . . . . . . $20 \mathrm{~g}$.

It was intended to observe the first year the effect of the most favorable conditions, hence the manure. In the following years there will be no manuring, to observe also the effect of carbon bisulphide in this case.

In the first plot 8 holes were made, each receiving 50c.c. bisulphide of carbon whereupon each hole was filled at once with earth. Finally water was poured on the surface to close the pores and then the soil was trodden. This application was made 30 days before sowing. At that time also potassium permangnate solution highly diluted was applied, plot No. 2 receiving 200 g., plot No. 3 only 50 g. of this salt. Plot No. 4 served as check.

3. Cf. Bulletin, College of Agriculture, Tokyo, Vol. VI, p. 104. 
Each plot received 9 bundles, each of 12 healthy plants of upland rice, which were reduced later on to 7 of nearly equal size. The variety of rice chosen was Kirishima. The weather conditions were exceedingly favorable during the whole time of vegetation and no disturbing factors had occurred. It was noticed during the summer that the plants of plot No. 1 were of the most luxuriant development and the color of the leaves were of the deepest green.

On October 4 the harvest was gathered and the following fresh weights obtained:

Harvest, $g$. 2962.5

Plot. No. 1, Bisulphide of carbon

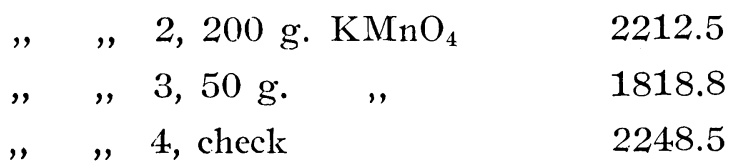

The harvest was now left to become airdry and then the following figures were obtained:

\begin{tabular}{|c|c|c|c|c|c|c|}
\hline & $\begin{array}{c}\text { Aver. } \\
\text { hts, cm. }\end{array}$ & $\begin{array}{c}\text { Total } \\
\text { wt., g. }\end{array}$ & $\begin{array}{l}\text { Wt. of } \\
\text { grain, g. }\end{array}$ & $\begin{array}{l}\text { Wt. of } \\
\text { straw, g. }\end{array}$ & $\begin{array}{c}\text { Aver. } \\
\text { number of } \\
\text { branches }\end{array}$ & $\begin{array}{c}\text { Comparative } \\
\text { harvest } \\
\text { cleck }=100\end{array}$ \\
\hline $\mathrm{CS}_{2}, 400 \mathrm{~g}$. & 136 & 1732.5 & 510.0 & 1222.5 & $5-6$ & 140.4 \\
\hline $\mathrm{KMnO}_{4} 200 \mathrm{~g}$. & 108 & 1083.7 & 303.7 & 780.0 & $4-5$ & 87.8 \\
\hline$\Rightarrow \quad 50 \mathrm{~g}$. & 119 & 1040.4 & 301.5 & 738.0 & $3-4$ & 84.3 \\
\hline Check & 122 & 1233.3 & 398.5 & 843.8 & $4-5$ & 100.0 \\
\hline
\end{tabular}

This result shows for the $\mathrm{CS}_{2}$-plot an increase of total harvest of $40.47 \%$; of grain $30.93 \%$; the accompanying photograph will show the superiority of this harvest.

It was a matter of surprise that a depression of harvest has taken place on the plots with $200 \mathrm{~g}$. and $50 \mathrm{~g}$. potassium permanganate. ${ }^{4)}$ This result was the more unexpected as manganese compounds can act as stimulants. The probable explanation is that by the oxidising action of this salt on humus injurious acids were produced.

4. Other authors have observed an decrease after application of that salt. 
The experiment will be continued also in this line to reach a decisive explanation,

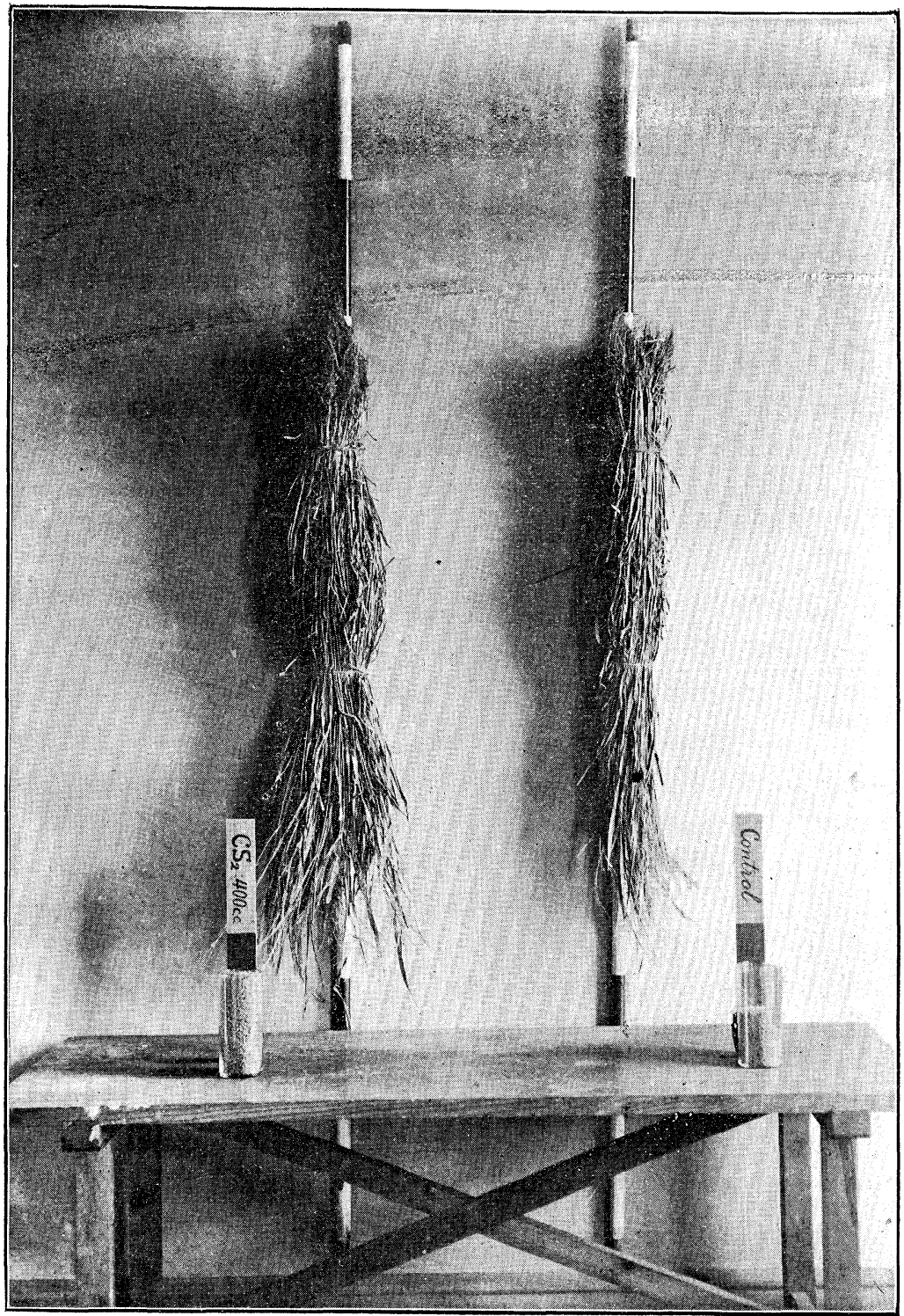

